Драган Милошевић

Народна библиотека Србије

dragan.milosevic@nb.rs
Стручни рад

UDK 025.343.2:93/94

025.45.02:93/94

https://doi.org/10.18485/

bibliotekar.2018.60.1.3

\title{
ПРЕДМЕТНА КЛАСИФИКАЦИЈА „ИСТОРИЈЕ” КРОЗ ПРИМЕРЕ ИЗ ПРАКСЕ НАРОДНЕ БИБЛИОТЕКЕ СРБИЈЕ
}

Сажетак: Овим радом покушаћемо да покажемо сву сложеност класификације на пољу историје. Одговарајућим примерима свакако је најбоље представити сложеност и разноликост могућности, али пре свега и потребу за решењима која могу да задовоље предметно одређивање, односно класификацију одређеног рада, књиге, научног дела. Сви примери у раду преузети су из праксе Народне библиотеке Србије. Историја као носилац или као саставни део предметне одреднице и УДК може на добар и сложен начин да опише и представи публикацију. У овом раду покушали смо да покажемо и могућност када није нужно у предметном делу експлицитно показати да је нешто „историја”, а да тим изостављањем ни на који начин класификатор неће „оштетити” једну пубилакцију. Коначно, показали смо примерима и како се предметно могу успостављати односи два броја из УДК таблица и тиме јасно и недвосмислено приказати садржину једне публикације.

Кључне речи: предметна класификација, стручна класификација, одредница, УДК, историја, стварни каталог, усвојени термин, неусвојени термин.

Ако се пође од познате латинске изреке која каже да је „историја учитељица живота"' (Historia magistra vitae est!), много тога се може окарактерисати као „историја”. Системом УДК (Универзална децимална класификација) могуће је класификовати одређену публикацију на више начина и тиме „историја“ може добити главну или пратећу карактеристику.

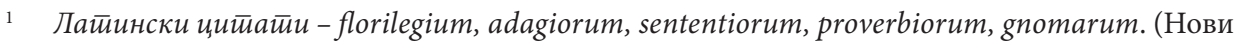
Сад: Матица српска, 1984), 151. 


\section{Предметна и стручна класификација према УДК систему}

Предметна класификација је настала из потребе за обједињењем информација о садржају грађе лисног каталога употребом контролисаног речника који је заснован на природном језику. Очигледно је да са становишта библиотечких корисника предметна класификација ствара разумљивије и једноставније алате за претраживање од стручне класификације, која захтева познавање децималних класификационих система намењених библиотечким стручњацима.

Предметни каталог библиотеке је ,један од стварних каталога који путем предметних одредница и предметних рубрика, лексикографски сређених и успостављених логичних веза међу њима, представља предмет, тему или садржај публикација које улазе у фонд библиотеке."2 У изради предметног каталога важе начела доследности примене јединствених изабраних термина - предметних одредница и пододредница, успостављање система еквивалентних, хијерархијских и асоцијативних веза међу њима.

Термин који класификатор одабира за предметну одредницу мора бити што прецизнији и једнозначнији, колико то природа језика дозвољава. С друге стране, одредница сваког типа мора бити термин прихваћен од стране научне заједнице, или у савременој говорно-језичкој пракси. Предметна класификација је неминовно условљена и језичким осећајем, знањем и свакако субјективним опредељењима класификатора, али сви ови недостаци произлазе из захтева да се природни језик „уклопи” у класификационе схеме а да се притом садржај неког извора у тим схемама што верније опише. Усвојени термин се доследно примењује у класификацији свих врста извора са истом темом.

Док се предметном класификацијом утврђује садржај извора и исказује контролисаним речником кроз једну или више предметних рубрика, стручна класификација има за циљ да додели одговарајуће класификационе ознаке за тај садржај у оквиру неке од стручних области. Уређење стручног каталога је хијерархијско, за разлику од предметног где се одреднице нижу алфабетским редом.

Предност УДК је коришћење помоћних знакова, могућност изражавања специфичних аспеката и односа предмета класификације. Циљ

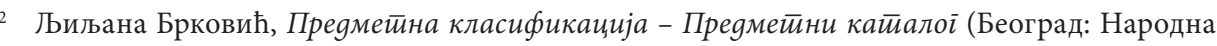
библиотека Србије, 1997), 9. 
УДК је да се у хијерархијској структури прикажу све науке и вештине, а полазна подела је на десет ${ }^{3}$ основних група које се даље деле на подобласти. На тај начин је успостављена класификација целокупног људског знања и активности, потпуно независна од језика (користе се децимални бројеви и додатни симболи, а словни карактери само изузетно). Класификациони систем је отворен за даљи развој који треба да прати новине у социјалном, научном, технолошком и уметничком животу човечанства.

\section{Група Историја у УДК таблицама}

Друштвене науке (социологија, психологија, политичке науке, историја итд.) у епистемолошком смислу (из грчког єльбтй знање) нејединствене су, како унутар себе, тако и у међусобном односу. У класификацији, и стручној и предметној, то се често рефлектује као релативна неодређеност или недовољна прецизност, нарочито у поређењу са класификацијом у природним наукама.

Савремени трендови у свим, па тако и у друштвеним наукама паралелно се крећу у правцу специјализације и интердисциплинарности. Данас је прилично тешко утврдити јасне границе између појединих дисциплина. Настају хибридне области проучавања које се не могу сврстати у један одељак класификационе схеме. Самим тим за библиотечке класификаторе изазов је да креирају адекватне и поуздане метаинформације о садржају научног и другог стваралаштва.

У другој половини последње декаде 20. века у гласилу УДК Конзорцијума Extensions and Corrections to the UDC објављиване су сукцесивно измене које се односе на групу Историја у оквиру класе 9 УДК таблица. Народна библиотека Србије током 2002. године почела је са применом нових УДК таблица за стручну класификацију библиотечке грађе из области историје $\mathrm{e}^{4}$

Основни број који заправо означава групу у којој је по подели историја јесте број 9 (девет). У групи 9 налазе се: ГЕОГРАФИЈА, БИОГРАФИЈА и ИСТОРИЈА.

Примери који следе вероватно најбоље показују суштину онога што се у овом раду жели представити.

3 Девет група је тренутно у употреби - група 4 је без садржаја.

4 Љуба Јањетовић, Измена УДК йаблица у груйи истиорија (Београд: Народна библиотека Србије, 2004) http://www.nb.rs/view_file.php?file_id=598 (преузето 25. 03. 2018). 


\section{ОПШТА ИСТОРИЈА}

CIP - Каталогизација у публикацији

Народна библиотека Србије, Београд

94(497.11)»04/14»

БЛАГОЈЕВИТ, Милош, 1930-

Српски сабори и сабори отачаства Немањића и Лазаревића / Милош Благојевић. - Стр. 1-40

Напомене и библиографске референце уз текст. - Апстракт ; Summary.
a) Државна управа - Србија - Средњи век
b) Србија - Историја - Средњи век
COBISS.SR-ID 516757911

Из наведеног примера који се налази у бази COBISS.SR ${ }^{5}$ коју користи Народна библиотека Србије видимо да је за публикацију Срйски сабори и сабори ойачасивва Немағића и Лазаревића коришћен основни УДК 94, који означава историју, док у загради имамо дат географски помоћни број 497.11 (који означава Србију) и означено време, у овом примеру „средњи век” «04/14». Тако да они који познају систем УДК или пред собом имају таблице веома лако могу да се снађу и схвате да публикација коју имају у рукама заправо говори о историји Србије у средњем веку.

Систем каталогизације је тако уређен да се ни онима који не познају УДК не оставља за размишљање пуно простора јер сваку каталошку јединицу и ЦИП запис прати и предметна одредница (једна или више), а у наведеном примеру то су:

\section{1. а) Државна управа \\ у) Србија \\ z) Средњи век}

5 Сви примери коришћени у овом раду су из базе COBISS.SR. 


\section{a) Србија \\ х) Историја \\ z) Средњи век}

Кратко речено, дилеме нема и све је јасно и за онога ко само тражи податке и референце, али и за онога ко ће евентуално читати дату публикацију.

*Кратко појашњење - у систему COBISS у којем раде класификатори у Народној библиотеци Србије (и другим библиотекама на територији Републике Србије, али и у земљама у окружењу) поља означена бројем $6 \mathrm{XX} \mathrm{су} \mathrm{поља} \mathrm{предметне} \mathrm{и} \mathrm{УДК} \mathrm{класификације.} \mathrm{Поља} \mathrm{има} \mathrm{више} \mathrm{и} \mathrm{означена}$ су бројевима - 600, 601, 602, 605, 606, 607 и 610 . Најчешће су у употреби следећа поља:

600 - Лично име као предметна одредница

601 - Назив корпорације као предметна одредница

602 - Породично име као предметна одредница

606 - Тематска предметна одредница

607 - Географска предметна одредница

док је поље

675 - Универзална децимална класификација (УДК).

У оквиру ових поља постоје и потпоља у која се уносе они битни подаци који заправо као целина граде суштину поља у којем се налазе. Најчешће су у употреби:
a - Почетни елемент
b - Преостали део имена (у пољу 600)
с - Додаци имену
f - Датуми (није временска пододредница!)
x - Тематска пододредница
y - Географска пододредница
$\mathbf{z}$ - Временска пододредница
w - Формална пододредница

а потпоље 6 су подаци за повезивање, који се користе када имамо потребу за уношењем упутних појмова, неусвојених одредница.

У примерима који следе неће бити овако детаљних објашњења поља и потпоља, али избор је тако сачињен да укаже на разноврсност и, надамо се, отклони све дилеме о начину рада и употреби свих, или бар већине, 
могућности коришћења УДК система. Примери из базе дати су у целини како би било јасно шта се желело рећи, односно на шта се желело посебно указати (а и ради проверљивости датих примера).

\section{ИСТОРИОГРАФИЈА}

CIP - Каталогизација у публикацији

Народна библиотека Србије, Београд

930.1:316.75(497.11)»1815»

94(497.11)»1815»

\section{ТИМОТИЈЕВИТ, Мирослав}

Таковски устанак - српске Цвети : о јавном заједничком сећању и заборављању у симболичној политици званичне репрезентативне културе / Мирослав Тимотијевић. - Београд : Историјски музеј Србије : Филозофски факултет, 2012 Београд : Типографик плус). - 596 стр. : илустр. ; $28 \mathrm{~cm}$

Тираж 600. - Напомене иу библиографске референце уз текст. - The Takovo Uprising - Serbian Palm Sunday. - Библиографија: стр. 539-575. - Регистар.

ISBN 978-86-82925-51-4

\section{a) Други српски устанак 1815 \\ COBISS.SR-ID 190839564}

Пример публикације Таковски устианак - срӣске Цветии... добар је пример у којем се као УДК користи 930, у овом конкретном случају 930.1, који према УДК таблицама има тумачење: Историја као наука; Теорија и филозофија историје; Структура и форма историје. Овај пример је сложенијег карактера, али како ћемо се у овом раду вратити на сличан пример, оставимо у овом тренутку само ово објашњење.

Свакако је неопходно нагласити да је поље деловања класификатора, иако омеђено, у суштини јако широко и у предметном делу и оставља пуно простора за усавршавање и стручну обраду, што, наравно, за резултат увек има боље и боље класификовање, а тиме се база података употпуњује и добија на квалитету. 


\section{Примери „прожимања” историје - кратки преглед}

Пређимо сада на примере у којима ћемо покушати да обајснимо „прожимање” историје са другим областима стварности, рада, науке итд.

\section{Пример 1.}

CIP - Каталогизација у публикацији

Народна библиотека Србије, Београд

355:929 Карађорђе

94(497.11)»1768/1817»

ГОФМАН, Владимир Е.

Велики Вожд Кара-Ђорђе / Владимир Е. Гофман. - Београд : Књига-комерц, 2001 (Београд : МД штампа). - 179 стр. : илустр. ; 20 cm. - (Библиотека Посебна издања / [Књига-комерц])

Штампано према изд. из 1930. - Тираж 1.000. - Родослов династије Карађорђевића / Душан Цветковић. - Библиографија: стр. 167-169.

ISBN 86-83583-06-6 (брош.)

a) Карађорђе (1768-1817) b) Србија - Историја - 1768-1817

\section{COBISS.SR-ID 183661831}

Публикација која нам већ својим насловом сасвим јасно говори да је у питању дело посвећено директно Карађорђу Петровићу, Велики Вожg Карађорђе, може се из угла каталогизатора сагледати и као биографско дело, што је и најјача карактеристика садржаја, али и као дело које нам говори о историји Србије у периоду у коме је живео и деловао Карађорђе. Баш зато је урађено тако да се публикација предметно води на личност:

a) Карађорђе (1768-1817) -355:929 Карађорђе

али и географски:

б) Србија - Историја - 1768-1817 \94(497.11)»1768/1817». 
Оваквом предметном одредницом и УДК системом класификатор је лепо и прецизно представио да у рукама држи публикацију која је биографија (означена карактеристичним УДК бројем 929), а како је Карађорђе био врховни командант устаницима, онда се то прикаузје УДК класификацијом бројем 355. Публикација нам доста говори и о историјским дешавањима у временском периоду који је наведен, те тако имамо 94 за историју, затим географски помоћни број за Србију (497.11) и године које увек иду под наводницима.

\section{Пример 2.}

CIP - Каталогизација у публикацији Народна библиотека Србије, Београд

930.85(495.02)

$316.72(495.02)$

39(495.02)

ЧЕКАЛОВА, Александра А.

Život i običaji u vizantijskom društvu / Aleksandra A. Čekalova, Margarita A. Poljakovska ; prevod sa ruskog Vera Janićijević. - Beograd : Pešić i sinovi, 2003 (Beograd : Atelje Sava). - 217 str. ; 21 cm

Prevod dela: Культура Византии. - Tiraž 500. - Napomene i bibliografske reference uz tekst.

ISBN 86-7540-031-4 (broš.)

1. Пољаковска, Маргарита А. [аутор] 2. Јанићијевић, Вера [преводилац]

a) Свакодневни живот - Византија b) Византија - Културна историја COBISS.SR-ID 110576396

У овом примеру публикација Животи и обичаји у визанйијском

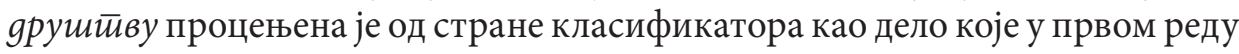
покрива друштвени/социолошки аспект, а онда и велико поље културне историје, и стога је предметно обрађено као:

а) Свакодневни живот - Византија > 316.72(495.02)

б) Византија - Културна историја \$930.85(495.02) 
У овом примеру нам се јавља географски помоћни број за државу која више не постоји, али како је Византијско царство било дугог трајања и обележило историју цивилизације, у УДК таблицама постоји карактеристичан број. Овде имамо дат и УДК: 39(495.02) - Број 39 у УДК таблицама означава: ЕТНОЛОГИЈА, ЕТНОГРАФИЈА, ОБИЧАЈИ, НАВИКЕ, ТРАДИЦИЈЕ, НАЧИН ЖИВОТА, ФОЛКЛОР, а тиме је класификатор желео корисницима да предочи још једну важну карактеристику ове публикације, свакако везану за садржај.

\section{Пример 3.}

CIP - Каталогизација у публикацији Народна библиотека Србије, Београд

$325.3(=112.2)(497.113) » 16 / 18 »$

$314.113(=112.2)(497.113) » 16 / 18 »$

94(497.113)»16/18»

\section{БЕШЛИН, Бранко}

Насељавање Немаца у Војводини / Бранко Бешлин ; [карта Александар Станојловић]. - Нови Сад : Платонеум, 2006 (Нови Сад : Scan studio). - 31 стр. : илустр. ; 24 cm

Кор. насл. - Тираж 500.

ISBN 86-85869-08-0 (брош.)

ISBN 978-86-85869-08-2

a) Немци - Насељавање - Војводина - 17-19в

b) Колонизација - Војводина - 17-19в

c) Војводина - Историја - 17-19в

COBISS.SR-ID 213252359

У примеру Насељьвағе Немаца у Војвоgини видимо како је публикација која говори о проблему колонизације добила у каталогизацији више одредница које публикацију у потпуности описују:

a) Немци - Насељавање - Војводина - 17в-19в >314.113(=112.2)(497.113)»16/18»

b) Колонизација - Војводина - 17в-19в -325.3(=112.2)(497.113)»16/18»

c) Војводина - Историја - 17в-19в Р94(497.113)»16/18» 
Није вишак нагласити да се у овом примеру јавља помоћни број за народе (и расе) јер публикација говори о територији Војводине (изражено бројем (497.113)), али разматра насељавање Немаца и стога је било неопходно то изразити у предметној и УДК класификацији - =112.2.

\section{Пример 4.}

CIP - Каталогизација у публикацији

Народна библиотека Србије, Београд

314.15-024.64(497.13)»1946»(093)

325.54(=163.41)(497.13)(093)

94(497.1)»1941/1945»:929

355.1-058.65(497.13)»1990/1997»(093)

ШИКАЊА, Бранко Д.

Колонисти Баније, Кордуна и Западне Славоније, насељени у Тење 1946. године и борци Тења / Бранко Д. Шикања. - Београд : Б. Д. Шикања, 2005 (Земун : Флеш). - 136 стр. : илустр. ; 21 cm. - (Библиотека Трагови / [Б. Д. Шикања])

Ауторова слика. - Тираж 400. - Библиографија: стр. 129.

\section{ISBN 86-906463-0-2}

a) Колонизација - Тења - 1946 - Историјска грађа

b) Срби - Насељавање - Тења - Историјска грађа

c) Народноослободилачка борба 1941-1945 - Учесници - Историјска грађа

d) Жртве рата - Тења - 1990-1997 - Историјска грађа

e) Тења

COBISS.SR-ID 118951436

Можда би се могло поставити питање - зашто опет сличан пример?! Одговор даје пажљиво читање каталошког записа. Овде се на примеру јасно види како систематски може бити обрађена једна вишеслојна публикација разноликог садржаја. Свакако нимало лака за класификацију, поготово у свом предметном делу. Рашчланимо публикацију Колонисиии Баније, Корууна и Зайаgне Славоније, насељени у Теґе 1946. године и бории Тењ $а$ како би нам се показала у јасном светлу: 
а) Колонизација - Тења - 1946 - Историјска грађа>314.15-024.64(497.13) "1946»(093)

b) Срби - Насељавање - Тења - Историјска грађа >325.54(=163.41)(497.13)(093)

c) Народноослободилачка борба 1941-1945 - Учесници - Историјска грађа ^94(497.1)»1941/1945»:929

d) Жртве рата - Тења - 1990-1997 - Историјска грађа

-355.1-058.65(497.13)»1990/1997»(093)

Осим већ анализираног у ранијим примерима, овде се појављује и помоћни број за облик - (093) - који нам казује да је у питању историјска грађа, што је и наведено у предметној пододредници.

\section{Пример 5.}

СIP - Каталогизација у публикацији

Народна библиотека Србије, Београд

355:929 Пејић П.

$343.819 .5 / .7 » 1941 / 1946 »(093.3)$

ПЕЈИЋ, Предраг

Сећања официра непокорене војске Краљевине Југославије / Предраг Пејић. - Београд : Српска реч, 2000 (Београд : Цицеро). - 163 стр. : илустр. ; 20 cm. - (Библиотека Српске речи)

Тираж 500. - На пресавијеном делу кор. листа ауторова слика и белешка о њему.

ISBN 86-491-0043-0 (брош.)

a) Пејић, Предраг (1917-) - Мемоари

b) Логори - Други светски рат 1939-1941 - У успоменама

COBISS.SR-ID 87460108

Пример који видимо показује нам како можемо да једну целу причу из прошлости Сећана официра нейокорене војске Кральевине Југославије каталошки прикажемо а да при томе није нужно уйотиребитии број који üpū̄aga Груйu 9. Тако видимо да публикација која пред читаоца доноси сећања директног учесника рата може лепо бити предметно и УДК описана и без употребе карактеристичног броја 94: 
a) Пејић, Предраг (1917- ) - Мемоари > 355:929 Пејић П.

b) Логори - Други светски рат 1939-1941 - У успоменама $>343.819 .5 / .7$ »1941/1946»(093.3)

Пример нам добро показује да је каталогизација ишла логиком да се у пољу 675 свакако мора изразити да је аутор мемоара био војно лице (представљено бројем 355) и да се кроз сећања, а можемо рећи и кроз личну историју, пред читаоце доноси дело које говори о прошлости, али му је доминантна карактеристика мемоарска. Овде године „од 1941. до 1946.” практично замењују групу 94.

\section{Пример 6.}

CIP - Каталогизација у публикацији

Народна библиотека Србије, Београд

355.48

930.1(497.1)

МИЈУШКОВИЋ, Милутин

Војноисторијски списи / Милутин Мијушковић ; приредио Живко М. Андријашевић. - Београд : Службени лист СЦГ ; Подгорица : ЦИД, 2004 (Београд : Војна штампарија). - 232 стр. : ауторова слика ; $21 \mathrm{~cm}$. (Библиотека Посебна издања)

Тираж 500. - Стр. 5-10: Ријеч приређивача / Живко Андријашевић. Биљешка о писцу: стр. [233]. - Напомене и библиографске референце уз текст.

ISBN 86-495-0152-4 (картон)

1. Андријашевић, Живко [уредник] [аутор додатног текста]

a) Војна историја

COBISS.SR-ID 113849868

Пример публикације Војноисӣоријски сӣиси каталошки је тако обрађен да иако у наслову директно имамо поменуту историју као појам, сам класификатор је стручно обрадивши публикацију одлучио да се предметно и УДК изрази на начин који недвосмислено указује на добро познавање материје: 
a) Војна историја $>355.48$

али је употребљен и још један УДК - 930.1(497.1) - који нам појашњава други аспект публикације - историографски.

\section{Пример 7.}

CIP - Каталогизација у публикацији

Народна библиотека Србије, Београд

930:316.48(497.11)»1987/2007»

930(497.11)(091)

ЈОВАНОВИТ, Мирослав, $1962-$

Криза и историја : друштвена криза и историјска свест у Србији почетком 21. века / Мирослав Јовановић. - Стр. 89-113

Апстракт.

а) Друштвена криза - Историографија - Србија - 1987-2007 COBISS.SR-ID 147844876

Примером публикације Криза и истиорија: gрушитвена криза и ис-

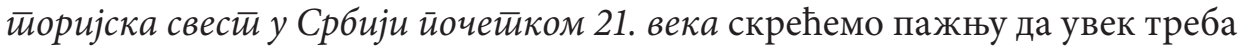
бити обазрив, добро проучити публикацију, те да се мора бити доследан и колико је год могуће прецизан у предметном одређивању. Тако овде имамо публикацију која би наизглед могла да носи број за историју, али већ наслов указује, а садржај и потврђује да опредељење за број 930 јесте права одлука класификатора:

а) Друштвена криза - Историографија - Србија - 1987-2007 ๑930:316.48(497.11)»1987/2007»

Свакако, дат је и број 930 јер ово дело јесте историографског карактера, док изабрани број 316.48 у УДК таблицама има тумачење - друштвени сукоби, социологија конфликата. 


\section{Пример 8.}

CIP - Каталогизација у публикацији

Народна библиотека Србије, Београд

\subsection{1:929 Сулејман II}

АФЈОНџУ, Ерхан, 1967-

Sultan Sulejman i Hurem / Erhan Afjondžu ; [prevod Saša Bradašević]. Beograd :

Narodna knjiga, 2012 (Beograd : Narodna knjiga). - 208 str. ; 20 cm

Prevod dela: Muthesem Süleyman ve Hürem Sultan / Erhan Afyoncu. - Tiraž 1.000. - Beleška o piscu: str. 205. - Napomene i bibliografske reference uz tekst. - Bibliografija: str. 197-202.

ISBN 978-86-331-3490-3

a) Сулејман II, турски султан (1494-1566)

COBISS.SR-ID 190852364

Овим каталошким записом може се лепо показати да је предметна одредница ишла на познату историјску личност:

\section{Сулејман II, турски султан $(1494-1566)>321.61: 929$ Сулејман II}

Дата је комбинација (однос) УДК који представља облик владавине (321.61) и број за биографије - 929, уз словне ознаке које су дозвољене у одређеним случајевима (у овом примеру исписано је пуно име у складу са каталошким правилима), свакоме ко има прилику да погледа каталошки запис биће јасно да је реч о делу које за тему има живот султана Сулејмана II. Како је Сулејман II веома позната личност из турске и европске историје, није било потребе за коришћењем било ког другог броја УДК. 


\section{Пример 9.}

CIP - Каталогизација у публикацији

Народна библиотека Србије, Београд

355.084:929 Затлер Б.

821.112.2-94

НИМАН, Беата, 1942-

Moj dobri otac : život sa njegovom prošlošću : biografija moga oca zločinca / Beata Niman ; [prevod Ljiljana Glišovićc. - Beograd : Službeni Glasnik, 2012 (Beograd : Glasnik). - 202 str. : ilustr. ; 23 cm. - (Biblioteka Društvo i nauka. Edicija Istorija / Službeni Glasnik)

Prevod dela: Mein guter Vater / Beate Niemann. - Tiraž 500. - Biografski podaci o Brunu Zatleru: str. 191-192. - Spisak skraćenica: str. 193-194. - Napomene i bibliografske reference uz tekst. - Bibliografija: str. 195-202.

ISBN 978-86-519-1200-2 (broš.)

а) Затлер, Бруно (1898-1972)

COBISS.SR-ID 189662732

Каталошким записом публикације Mој gобри ойаu - животи са юеговом иррошлошћу - биограбија мога оца злочиния желели смо да дамо пример када се може употребити број за роман, али роман са биографским/ аутобиографским карактером: 821.112.2-94

\section{а) Затлер, Бруно (1898-1972) - 355.084:929 Затлер Б.}

Овде се класификатор одлучио да у односу на саджај ову публикацију представи тако да кориснику каже како је то роман, са пуно аутобиографских елемената, који спада у немачку књижевност (821.122.2), али је у овом случају у односу на садржај употребљен и број који је означио да је у питању и биографија, што се види из горе издвојеног сегмента каталошког записа (355.084:929). 


\section{Пример 10.}

CIP - Каталогизација у публикацији Народна библиотека Србије, Београд

37.016:94(075.2)(076)

ЧИТАНКА Првог српског устанка / [текстове приредио Борисав Челиковић]. - Горњи Милановац : Дечје новине „Доситеј”, 2012 (Горњи Милановац : Ленарт). - 34 стр., [4] листа с таблама : илустр. ; 30 cm

Тираж 1.000. - Речник мање познатих речи: стр. 33.

ISBN 978-86-7644-067-2

COBISS.SR-ID 189476364

Не можемо прескочити ни публикације намењене настави историје и овим примером смо желели да покажемо како се каталогизује једна историјска читанка. Коришћени су карактеристични бројеви за овакву врсту публикација у односу и кроз систем УДК јасно је представљено да се ради о уџбенику за средњу школу - (075.2) - помоћни бројеви за облик увек се дају у загради - и сасвим конкретно о приручнику за извођење наставе - (076).

Све то је „речено” као: 37.016:94(075.2)(076)

а ради потпуног објашњења рецимо да број 37.016 означава Наставни програм (предмети на било ком нивоу) и у односу (што се представља симболом двотачке) на број 94, и недвосмислено говори да је реч о уџбенику, односно историјској читанци.

\section{Пример 11.}

CIP - Каталогизација у публикацији

Народна библиотека Србије, Београд

94(=411.16)(497.11)»1941/1945»(083.824)

$323.12(=411.16)(497.11) » 1941 / 1945 »(083.824)$

ФОГЕЛ, Ненад, 1950-

Pravednici iz Srbije : izložba o dobrim ljudima = Erényesek Szerbiaból : kiallitás a nemes emberekől $=$ The Righteous of Serbia : an exhibition about 
good people / [[autor teksta u katalogu Nenad Fogel] ; prevod na engleski Olivera Polajnar ; prevod na mađarski Estera Lenhart Mesaroš]. - Beograd : Jevrejska opština Zemun, 2012 (Kragujevac : Grafostil). - [28] str. : fotogr. ; $24 \mathrm{~cm}$

Uporedo srp. tekst i mađ. i engl. prevod. - Tiraž 1.000.

ISBN 978-86-88297-05-9

a) Јевреји - Србија - 1941-1945 - Изложбени каталози

b) Јевреји - Прогони - Србија - 1941-1945 - Изложбени каталози COBISS.SR-ID 189926924

Пример изложбеног каталога Правеgници из Србије - изложба о gобрим лудима указује на могућност употребе карактеристичног броја за историју и за публикацију оваквог типа:

a) Јевреји - Србија - 1941-1945 - Изложбени каталози >94(=411.16)(497.11)»1941/1945»(083.824)

b) Јевреји - Прогони - Србија -1941-1945 - Изложбени каталози -323.12(=411.16)(497.11)»1941/1945»(083.824)

Овде се класификатор определио за две предметне одреднице и за два УДК броја и у првом делу јасно исказао да је реч о Јеврејском народу (=411.16) - у Србији - (497.11) - у периоду Другог светског рата - «1941/1945» - и наравно на крају је и окарактерисана публикација, односно и бројевима је исказано да је у питању каталог изложбе - (083.824).

Друга одредница нам својим првим бројем - 323.12 - управо појашњава оно што је у предметном делу исказано речима (речју) - Прогони. У УДК таблицама број 323.12 има тумачење - Покрети против одређених раса или националности. 


\section{Пример 12.}

CIP - Каталогизација у публикацији

Народна библиотека Србије, Београд

$001.9(100)(031)$

930.85(031)

KAKO je sve počelo : istine i zablude o svetu koji nas okružuje / [pisci Toni Alen ... [et al.] ; fotografije Kerolajn Vud ... [et al.] ; prevod sa engleskog Eva Koprivica] ; uvodna reč Ejze Brigsa. - Beograd : Mladinska knjiga, 2012 (Ljubljana : Koraton). - 320 str. : ilustr. ; 28 cm

Prevod dela: How It All Started. - Tiraž 3.200. - Uvodna reč Ejze Brigsa: str. 7. - Registar.

ISBN 978-86-7928-356-6

1. Ален, Тони [аутор]

а) Цивилизавија - Историја - Енциклопедије COBISS.SR-ID 189651980

Ако пред собом имамо публикацију енциклопедијског карактера, свакако да нам се историја у неком свом облику меша и у ту врсту штампаних или меморисаних материјала:

а) Цивилизавија - Историја - Енциклопедије $>01.9(100)(031) 930.85(031)$

Овде је класификатор предметно правилно окарактерисао публикацију и употребио је две УДК ознаке које кориснику говоре да је у питању област популаризације науке - 001.9; искоришћен је географски помоћни број - (100) - који означава да је у питању публикација која обухвата област целе планете и помоћни број који нам означава да је по среди енциклопедија - (031).

Број 930.85 нам говори да је то - Културна историја; историја цивилизације. 


\section{Пример 13.}

CIP - Каталогизација у публикацији

Народна библиотека Србије, Београд

728.81(497.11)»18»(083.824)

94(497.11 Ваљево)»18»

КРИВОШЕЈЕВ, Владимир

Кула Ненадовића / [аутори поставке и каталога Владимир Кривошејев, Катарина Марковић]. - Ваљево : Народни музеј, 2012 (Ваљево : Valjevo Print). - 27 стр. : илустр. ; 21 x 30 cm. - (Библиотека Каталози / Народни музеј Ваљево)

Тираж 2.000. - Напомене и библиографске референце уз текст.

ISBN 978-86-84893-19-4

1. Марковић, Катарина [илустратор] [аутор изложбе]

a) Ваљево - Кула Ненадовића - 19в - Изложбени каталози

b) Ваљево - Историја - 19в

COBISS.SR-ID 189628940

Размотрићемо пример још једног изложбеног каталога у коме ћемо видети да се историја прожима и у области архитектуре и да се такав однос може лако и добро каталошки приказати:

a) Ваљево - Кула Ненадовића - 19в - Изложбени каталози -728.81(497.11) "18»(083.824)

b) Ваљево - Историја - 19в $\gg 94(497.11$ Ваљево)»18»

Како би овај пример био довољно описан и указујући, овде је потребно нагласити следеће: број из УДК Таблица - 728.81 - има тумачење: Замкови (утврђени и полуутврђени), што овде описује и део наслова и основу садржаја, а други УДК број недвосмислено говори да је реч о историји одређеног периода и сасвим одређеног места. Правила дозвољавају, али само у неколико случајева, а такав јесте случај са облашћу историје (94), да се у загради поред помоћног броја за државу словима упише назив места, уколико то доприноси најпрецизнијој каталошкој обради. У овом примеру управо тако се и поступило приликом каталогизације - 94(497.11 Ваљево)»18». 


\section{Пример 14.}

CIP - Каталогизација у публикацији

Народна библиотека Србије, Београд

930.2:003.074(560)(075.8)

091 $=512.161(075.8)$

003.072 $=512.161(075.8)$

ЧОЛИЋ, Љиљана, 1956-

Османска дипломатика са палеографијом / Љиљана Чолић. - 2. измењено и допуњено изд. - Београд : Завод за уџбенике, 2012 (Београд : Службени Гласник). - 197 стр. : факс. ; 29 cm

Део текста упоредо на тур. и срп. језику. - Тираж 500. - Речник османских термина: стр. 187-191. - Напомене и библиографске референце уз текст. Библиографија: стр. 193-197.

\section{ISBN 978-86-17-17979-1 (брош.)}

\section{a) Турска дипломатика \\ b) Турска палеографија \\ COBISS.SR-ID 189522188}

Примером публикације Османска gийломатиика са йалеографијом показаћемо како и правилном комбинацијом бројева из УДК таблица можемо представити и ову област људског знања и деловања:

a) Турска дипломатика $\$ 930.2: 003.074(560)(075.8)$

b) Турска палеографија $>003.072=512.161(075.8)$

Појаснимо и овај пример: 930.2 у УДК таблицама значи: Методологија историје. Помоћне историјске науке. Проучавање засновано на писаним изворима, записима, посветама; 003.072 - Палеографија; 003.074 је број који означава Дипломатику, док је број за језик који у овом примеру имамо: $=512.161-$ турски (османски) језик. Када протумачимо и број $091-$ Рукописи - пред нама се заиста отвара врло јасан запис који је дат у децималној класификацији и заиста верно и доследно прати оно што је класификатор исказао речима у предметном делу записа. 


\section{Пример 15.}

CIP - Каталогизација у публикацији

Народна библиотека Србије, Београд

94(497.11)»1914/1918»

МИТРОВИЋ, Андреј

Србија у Првом светском рату / Андреј Митровић. - Допуњено изд. - Београд :

Стубови културе, 2004 (Сопот : АМД графика). - 603 стр. ; 20 cm

Тираж 1.000. - Напомене и библиографске референце уз текст. - Библиографија: стр. 579-583. - Регистар.

ISBN 86-7979-107-5 (брош.)

\section{a) Први светски рат 1914-1918 - Србија} COBISS.SR-ID 117434636

Шта се жели рећи овим примером? Једино то да није све бескрајно компликовано и да класификација у области историје може некада да буде „само то” - историја! Тако да у овом примеру крајње јасно имамо дат број који нам казује да је у питању историја Србије у Првом светском рату.

\section{Закључак}

У овом раду учињен је покушај да се укаже на сложеност класификације на пољу историје, што је илустровано репрезентативним примерима из праксе Народне библиотеке Србије. Показано је да се помоћу расположивог класификаторског алата исӣорија као носилац или као саставни део предметне одреднице и УДК броја на различите начине може искористити у предметном представљању једне пубилакције. Истовремено је указано да није увек неопходно у предметном делу експлицитно одредити нешто као uстиоријy, при чему се тим изостављањем ни на који начин не угрожава класификација једне пубилакције. На конкретним примерима је објашњено како се предметно могу успостављати односи два броја из УДК таблица и тиме јасно и недвосмислено приказати садржину једне публикације. 


\title{
Литература:
}

1. Brković, Ljiljana. Predmetna klasifikacija - Predmetni katalog. Beograd: Narodna biblioteka Srbije, 1997. (na ćirilici)

2. Janjetović, Ljuba. Izmena UDK tablica u grupi Istorija. Beograd: Narodna biblioteka Srbije, 2004. http://www.nb.rs/view_file.php?file_id=598 (preuzeto 25. 03. 2018). (na ćirilici)

3. Latinski citati - florilegium, adagfiorum, sententiorum, proverbiorum, gnomarum. Novi Sad: Matica srpska, 1984.

\section{Dragan Milošević}

The National Library of Serbia

dragan.milosevic@nb.rs

\section{SUBJECT CLASSIFICATION OF “HISTORY” IN THE PRACTICE OF THE NATIONAL LIBRARY OF SERBIA}

\begin{abstract}
This work tried to show all the complexity of classification in the field of history. Certainly, the best way to present the complexity and variety of possibilities is by giving the appropriate examples, but above all by giving solutions that can satisfy the given determination, or classification of a particular work. All examples were taken from daily practice of the National Library of Serbia.

History, as the bearer or as an integral part of the subject heading and the UDC number, can describe and present the publication in a good and complex way. In this paper, the possibility is presented when there is no need to explicitly show that something is "history" as the subject matter and that in this way the classifier will not "damage" the publication. Finally, examples are given how the relations of two numbers from the UDC tables can be established in the context, and thus clearly and unequivocally present the contents of a publication.
\end{abstract}

Keywords: subject classification, heading, subject catalogue, UDC, history, uniform heading, alternative heading.

Примљено: 15. априла 2018.

Исправке: 14. маја 2018.

Прихваћено: 25. маја 2018. 